\title{
STUDIES OF FACTORS AFFECTING URANIUM DETERMINATIONS BY AUTOMATED COULOMETRIC TITRATION (NEW BRUNSWICK LABORATORYI DAVIES-GRAY METHOD)
}

J. E. Harrar and W. G. Boyle

Apr11. 26, 1976

Prepared for U.S. Energy Research \& Development Administration under contract No. W-7405-Eng-48
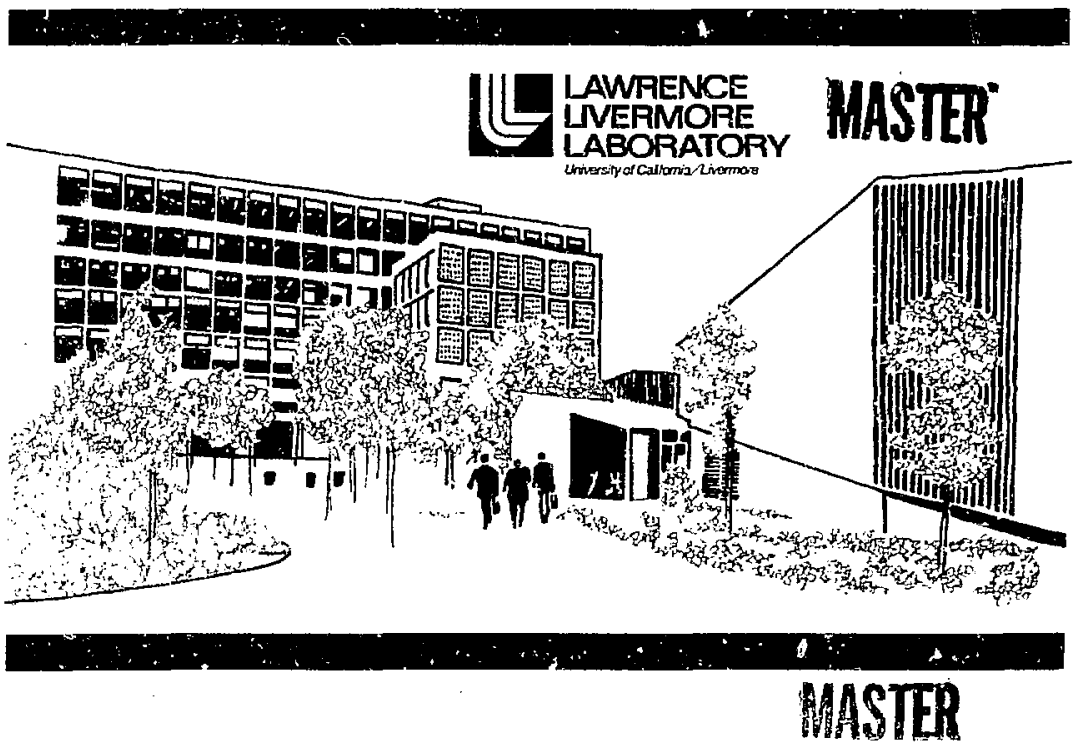


\section{NOTICE}

"This report was prepared as an account of wath sponsored by the Unlied States Government. Neilhet the United States nor the United States Energy Research \& Developmeni Adminbtration, nor any of their employet, nor any of their contractors, subcontractors, or theix employees, makes iny warranty, expross of implit d, at assumes any legal liability or tespensibility lor the nccuracy, compktencas or usefulness of any intormation, apperalus, product or process disclosed, or reprosents that lis use would not infrisige privately-owned rights."

Printed in the United States of America

Available from

National Technical Information Service

U.S. Department of Commerce

5285 Port Royal Road

Springfield, VA 22161

Price: Printed Copy \$ ; Microfiche \$2.25

Page Range

Domestic

001-025

026-050

051-075

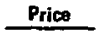

$076-100$

\$ 3.50

4.00

4.50

5.00

101-125

5.25

5.50

6.09

7.50

7.75

Dags Range

Dometic

126-150

8.00

$326-350$

Price

151-175

9.00

$351-375$

10.00

176-200

$376-400$

10.50

201-225

$401-425$

10.75

226- 250

9.25

276-300

9.75

$426-450$

11.00

11.75

$451-475$

12.00

476-500

12.50

$501-525$

12.75

526-550

13.00

$531-575$

13.50

$301-325$

$576-600$

13.75

601-up

Add $\$ 2.50$ for each additional 100 page increment from 601 to 1,000 pages: add \$4.50 for each additional 100 page increment over 1,000 pages. 


\section{辿 \\ LAWRENCE IIVERMORE LABORATORY}

Unverstyol Catroma Lnemore. Callorna 94550

\section{LCRL-5:OKO \\ STUDIES OF FACTORS AFFECTING URANIUM DETERMINATIONS BY AUTOMATED COULOMETRIC TITRATION (NEW BRUNSWICK LABORATOFY/ DAVIES-GRAY METHOD)}

J. E. Harrar and W. C. Boyle

Sis, date: April 26, 1976

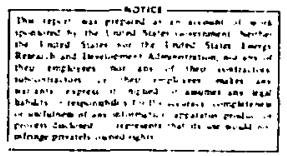

3.

$2: 4,2)$ 


\section{Contents}

ibsteract . . . . . . . . . . . . . . . . . . . . . . . . . 1

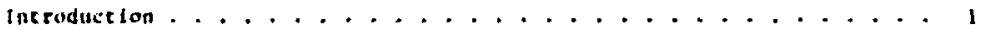

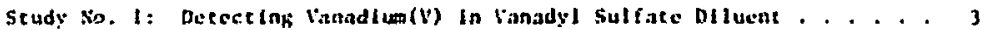

study to. 2: Loss of tranlua(IV) After bllution . . . . . . . . . . . s

ftudy No. 3: Comparison of txpezimencal with Theoretieal titration

Curves: Determination of End-Pofne Epror . . . . . . . . . . . . s

Study No. 4: Curzene-Potential Characterlstfes of Generator tilectrode:

IItration/Curtent Efflelency . . . . . . . . . . . . . . . . . Il

Study to. 5: Eiffect of Phosphoric Aeld Iopuritics an Operating

Potential of Generator bilectrode . . . . . . . . . . . . . . 13

Study No. 6: Reproductblltey of Reagent Solution Dellvery . . . . . . . 16

Referencess............................... 20

Appendix: Procedure for Testing vosos Solution for Vanadium( $\left.v^{*}\right)$

iy Controlled-potential Coulonetry . . . . . . . . . . . . . . 22 


\title{
STUDIES OF FACTORS AFFECTING URANIUM DETERMINATIONS BY AUTOMATED COULOMETRIC TITRATION (NEW BRUNSWICK LABORATORY/DAVIES-GRAY METHOD)
}

\begin{abstract}
Our work is part of a project to develop a corputer-automated systed based on the lew Beuniwlek taboratory/Davses-cisay method for coulometelc teration. For this particular set af studies, we intended to define the rastod's errors to ascertain 1 ts absolute arcuracy.

he developed an analytical techntque to examine vanadyl sulfate dluen: for vanidium(i). None could be found in any of the lots tested. cercain lots of reagent-grade phosphoris: as: id concained an unidentifled impurticy chat caused high generatorclectrode potentials and a positive error. We measured the currentpotential characteristics of the Benerator electrade. The data

indicated that a signiflcant fraction of uranium(IV) was oxidized directly duiling the early stages of titration. vising equations theoretically applicable to such a ticration, we found a regligible difference between the inflection point of the titration curve and the equivalence point in the titration. However, the actual experimental curves did not agree with the theoretical curves early in the titration.

Measurements of the background current Indicated a level equivalent

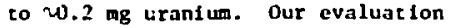
of the reagent delivery syster used In the automated analyzer revealed adequate reproducibility.
\end{abstract}

\section{Introduction}

The Lawrence LIvermore Laboratory (1.t.L) has a project to develop a computer-autonated system for the determination of the arount of uranium in solution. This system is based on the coulowetric titration method of Goldbeck and Lezner ${ }^{1-4}$ of the New Brunswick Laboratory (NBL).
Basically, this method involves:

- Reduction of uranium(VI) to uranium(IV) by reaction with fron(II) In strong phosphorlc actd $\left(\mathrm{H}_{3} \mathrm{PO}_{4}\right)$.

- Oxidation of excess iron(II) by reaction with nitric acid 
$\left(\mathrm{HNO}_{3}\right)$ catalyzed by

molybdenum(VI).

- Titration of uranfum(IV) with vanadium(v), which is

electrogenerated at controlled current.

The coulometric procedure is an extension of the volumetric method developed by Davies and Gray ${ }^{5}$ and refined by Eberle, et al. ${ }^{6}$ at NBL.

We have developed the equipment and instruntentation ${ }^{7}$ for automatically determining uranium. Our system can perform sample changing, pretitration reagent addition, titration. titration-curve data logging, endpoint calculation, result readout, and postetration solution disposal.

A method co determine urenium would be most useful if it linolves no systematir: error (blas). If the coulometric titration could be placed on an absolute basts, calculations of uranium quatitities could be based solely on the electrical calibrations of the inscrumentation. This would reduce the systematic error. Apart frow the posstbility of compensatiug errors, a blas-free determination would require:

\section{- Accurate chemical preparation} of uranium for titration.

- Negligible loss of urantum(IV) before completion of titration.

- Chemical and electrochemical equilibrium in the titration mixture when titration is completed (or end point reached).

- No intrinsic difference between the assumed end point and the true equivalence point.

- One-hundred percent current or titration 8 efflciency in the controlled-current electrolysis.

- Negligible errors in control of the current.

- Negligible timing errors. Our main goal was to define the errors in the automated coulometric titration method to ascertain its absolute accuracy. To this end, six mintstudies were conducted to examine (in more detall than before) some of the factors affecting the method's accuracy. He also examined several characteristics of the automated system as they relate to the coulometric titration.

The very high accuracy and precision of the volumetric procedure, as carried out with potasstum dichromate $\left(\mathrm{K}_{2} \mathrm{Cr}_{2} \mathrm{O}_{7}\right)$ tizrant, 5,9 p covide ample evidence that reduction of uranium(VI) to uranium(IV) is complete. These studies also showed that the iron and nitric aciomolybdenum(VI) reagents cause no errors. 


\section{Study No. 1: Dejecting Vanadium(V) in Vanadyl Sulfate Diluent}

In the volumetric procedure, vanadyl fon [vanadium(IV)] is added to the uranium(IV) solution to accelerate the attainment of equilibrlum in the ticration. ${ }^{6}$ This is also the precursor spectes from which the vanadace Ion [vanadium(V)] is electrogenerated in the coulometric procedure. Stnce vanadium(V) reacts directly with urantum(IV), Its presence in the vanady $\perp$ sulfate (Voso ${ }_{4}$ ) diluent added to the solution before titration would create a negative blas in the uranium determination. The voSO $_{4} \cdot 2 \mathrm{H}_{2} \mathrm{O}$ salt used to prepare the dilisent may contain vanadium( $V)$. Also, vanadfum( $V$ ) may arise from alr oxidation of the vanadyl fon $\left(\mathrm{VO}^{2+}\right)$ In the diluent. Eberle and Lerner ${ }^{10}$ previously Investigated the latter effect.

To test for the presence of vanadium (V) In VOSO $_{4}$, we developed a controlled-potential coulonetric (CFC) procedure that Involves the reduction of vanadium(V) to vanadium (IV) In $1.5 \mathrm{M} \mathrm{H}_{3} \mathrm{PO}_{4}$. The appendix detafls this procedure, which is based or a previously published method $^{11}$ that uses a platinum-workingelectrode cell. Since each determination has a sensitivity of 20.03 $\mathrm{mg}$ vanadium(V) and $2375 \mathrm{mg}$ vanadium(IV) is tested, the procedure can detect a level of $\mathbf{0 . 0 1 \%}$ vanadium(V). In the controlled-current coulometric method for uranium, In which 160 ml of a 0.025 voso $_{4}$ solution is added, the sensictuity of the CPC procedure is equivalent to $0.04 \mathrm{mg}$ urantum. Thus, a blas from this source should be detsctable at this level.

We used the CPC procedure to test seven different lots of Fisher Sclentific Company catalog number v-8 $\operatorname{voso}_{4} \cdot 2 \mathrm{H}_{2} \mathrm{O}$ of various ages (304634, $710500,722508,730999,732426$, 736791, and 790998) and one sevinyear-old sample of Research OrganicInorganic Chemicals catalog number V13 VOSO $_{4} \cdot 2 \mathrm{H}_{2} \mathrm{O}$.* We found no evidence of vanadium(V) in any of the materfal. There are strong oxidants other than vanadium(v) that could cause a blas in the uranium method, but most of these would also be detected in the CPC test.

Eberle and Lerner ${ }^{10}$ found that vanadyl solutions aged in air caused a negative bias when used in the uranium determination. They found

\footnotetext{
*Reference to a company or product name does not imply approval or recommendation of the product by the University of CaIifornia or the U.S. Energy Research \& Development Administration to the exclusion of orhers that may be suitable.
} 
spectrophotonetric evidence of

vanadium(V) in these salutions within a few hours of preparation. On the same basis as our test, they found a level of $0.25 \mathrm{mg}$ uranium equivaleat in the freshly prepared solution.

The appearance of vanadium(V)

in solucion is presulialy due to one or both of the reactions

$$
\begin{aligned}
2 \mathrm{VO}^{2+} & +\mathrm{O}_{2}+2 \mathrm{H}_{2} \mathrm{O}+2 \mathrm{vO}_{2}^{+}+2 \mathrm{H}^{+} \\
& +\mathrm{H}_{2} \mathrm{O}_{2},
\end{aligned}
$$

$$
4 \mathrm{VO}^{2+}+\mathrm{O}_{2}+2 \mathrm{H}_{2} \mathrm{O} \cdot 4 \mathrm{VO}_{2}^{+}+4 \mathrm{H}^{+},
$$

depending on the extent to which oxygen is reduced. It can be postulated that, in either case, the addition of actd to the diluent containilig vo ${ }^{2+}$ should ald in stabllizing the vo ${ }^{2+}$ against air oxidation. In the original volumetric method ${ }^{6}$ and in the tests on the diluent conducted by Eberle and Lerner, ${ }^{10}$ there was no actd in the diluent. However, in the Fisher Ittralyzer adaptation of the volumetric methed, ${ }^{6}$ and in the original coulometric method, 1 the diluent was made 1 M In sulfurlc acid $\left(\mathrm{H}_{2} \mathrm{SO}_{4}\right)$. In a later adaptation of the coulometric method for automatic operation, ${ }^{2}$ the diluent was $0.18 \underline{\mathrm{M}}$ $\mathrm{H}_{2} \mathrm{SO}_{4}$.
To test the stabillty of the diluent as a function of acid concentration, we prepared three solutions of $0.025 \mathrm{M}$ VOSO $_{4}$, piaced them in 250-m1 open beakers, and allowed them to stand at 20 to $26^{\circ} \mathrm{C}$ for three wonths. During this time, evaporative losses were replaced by water. At the end of this time, the vanadium(V) in the solut fon was determined by the CPC procedure. Table 1 shows the $r$. Its.

Table 1. Quane fty of vanadxum(V) in diluent after standing in air for 3 mo. Lot number $730999 \mathrm{VOSO}_{4} \cdot 2 \mathrm{H}_{2} \mathrm{O}$.

\begin{tabular}{cc}
$\begin{array}{c}\text { Acid } \\
\text { concencration } \\
(M)\end{array}$ & $\begin{array}{c}\text { Vanadium(y) found } \\
\text { (m8 U equivalent/ } \\
160 \mathrm{ml} \text { diluent) }\end{array}$ \\
\hline 0 & $\begin{array}{c}4.4 \\
0.18\end{array}$ \\
1.0 & 0.51 \\
\hline
\end{tabular}

The data cliarly show that acid decreases the rite of oxidation of the vanadium(IV). As a parallel expertment, we also studied the quantity of vanadium(V) appearing in the diluent used in the LI.L compucerautomated citration syster. After two months use, during which time the $0.18 \mathrm{M} \mathrm{H}_{2} \mathrm{SO}_{4}$ diluent was intermittently under $83 \mathrm{kPa}$ (12 psi) pressure 
uf air, the mg uranium equivalent/ $160 \mathrm{ml}$ was $0.60 \mathrm{mg}$.

As a rosult of these experiments, for the l.l.l. titration system we decided to make the cuncentrat lon of $\mathrm{H}_{2} \mathrm{Su}_{4}$ in the diluent $0.30 \underline{\mathrm{M}}$ and pressurize the reagent costainers with nitrogen or other inert gas rather than air. Nevertheless, it should still be possible to ase afr without error, if the diluent is consumed and replaced at frequent Intervals. It also appears feas $1 b_{1}$ : to increase the concentration of vanadium(IV) in the diluent. A benefit of this wonld be a decrease in the generator-electrode potential required to maintain a given level of constant current.

\section{Study No. 2: Loss of Uranium(IV) After Dilution}

Loss of uraniun(IV) after the dilution step, due to oxidation by $\mathrm{HNO}_{3}$, places an upper limit on the allowable titration time. An adequate discussion of this effect appears in two NBL publications. 1,6 Nother possible source of uranium(IV) loss, diffusion of the species into and through the cnunter-electrode separator material, hes sot been investigated but 13 helleved to be of minor importance. The solution contacts the separator only durling the ticration step, which never exceeds the aliokable maximum $r_{\text {me }}$ of $v_{B}$ min. Detexminations using both a Nafion ion-exchange membrane cube $e^{12}$ and a porous Vycor tube revealed no difference in recovery.

\section{Study No. 3: Comparison of Experimental with Theoretical Titration Curves; Determination of End-Point Error}

Previous applications of the deterifination of uranium by the Diavies-cray method and its extenslons, $1-4,6$ where potentiometric end-poinc detection was used, have been based on the end point as the noint of maximum slope ("inflection point") of the titration curve. Apart from the question of whether or not the Inflection point is accurately detected, we would ilke to know whether or not it actually coincides with the true equivalence point in theory for redox reactions of this rype. Such intrinsic errors, albett smal1, exist 13,14 for many such reactIons. Knowledge of the theoretical titration curve for our particular case (uranium/vanadium reaction) is needed to further establish that the 
coulometric titration can be placed on an absolute basis. One does not need this information for procedures in which the titrant is not a primary standard.
Table 2 shows the approximite composition of the titration medium, assuming the cumpositions of t":e reagents given and a "pure" uranim sample. For the species involved in

Table 2. Composition of reagents and final titration solution.

Couponert

Composition

Voitume

$\left(\mathrm{cm}^{3}\right)$

Sample

$0-18 \mathrm{M} \mathrm{H}_{2} \mathrm{SO}_{4}, 10-200 \mathrm{mg} \mathrm{v}$

Reagent 1

$1.5 \underline{\text { M sulfamic acid }}$

Reagent 2

$13.3 \mathrm{M} \mathrm{H}_{3} \mathrm{PO}_{4}, 0.11$ ㅌ $\mathrm{Fe}(\mathrm{II}), 0.001 \% \mathrm{Cr}$

Reagent 3

$8.0 \mathrm{M} \mathrm{HNO}_{3}, 0.15 \underline{\mathrm{M}}$ sulfauic acid.

$0.4 \%$ ammonium molybdate

Dfluent

$0.3 \mathrm{Y} \mathrm{H}_{2} \mathrm{So}_{4}, 0.025 \underline{\mathrm{M}} \operatorname{vosO}_{4}$

Titration solution

$$
\begin{aligned}
& 2.5 \underline{\mathrm{M} \mathrm{H}} \mathrm{PO}_{4} \\
& 0.34 \underline{\mathrm{MNO}} \mathrm{HN}_{3} \\
& 0.2-1.1 \mathrm{M} \mathrm{H}_{2} \mathrm{SO}_{4} \\
& 0.04 \underline{\mathrm{M}} \text { sulfamic acid } \\
& 0.02 \underline{\mathrm{M}} \mathrm{Fe} \text { (III) } \\
& 0.017 \underline{\mathrm{M}} \mathrm{V}(\mathrm{IV}) \\
& 0.2-4.3 \mathrm{mM} \mathrm{U} \\
& \text { small amts of Mo, Cr }
\end{aligned}
$$


this thtration, $\mathrm{H}_{3} \mathrm{PO}_{4}$ primarily

cietermines the formal potentials ant equilibria in the reaction system. The overall reaction in the titration is

$$
\begin{aligned}
\mathrm{NO}_{2}^{+}+ & \mathrm{NO}^{2+}+2 \mathrm{H}^{+} \\
& \mathrm{UO}_{2}^{2+}+2 \mathrm{NO}^{2+}+\mathrm{H}_{2} \mathrm{O} .
\end{aligned}
$$

For the vanidium half-reaction, Interpolating the data of Astakhina and Eurevich 15 ior $\mathrm{H}_{3} \mathrm{PO}_{4}$ gives a value of $E^{\circ}=+0.98 v$ ve SHE fGr $2.5 \mathrm{y} \mathrm{H}_{3} \mathrm{PO}_{4}$. where $E^{\circ}$ is the formal potential. Simllarly. Marcus' daca ${ }^{16}$ ylelds a value of $E^{\circ}=+0.52 \mathrm{~V}$ vs SHE for the $\mathrm{UO}_{2}{ }^{2+} / \mathrm{uO}^{2+}$ couple in $2.5 \mathrm{M} \mathrm{K}_{3} \mathrm{PO}_{4}$.

To determine wh:ether the ir:e equivalence point of the titration coinctles with the inflection point of the ticration curve, one must conetruct a theorecical curve of the fraction or percentage of substance ticraced vb the solucion redox potential (which, experimentally, is measured with the indicator electrode). Goldman derived an equation (Eq. 53 in Ref. 17) appropriate fur this purpose:

$$
\begin{aligned}
f= & \frac{1+k \cdot \exp \left(n_{1} \Psi\right)}{1+k \cdot \exp \left(-n_{2} \Psi\right)} \\
& +a_{\bar{K}}^{*}\left(n_{1} / n_{2}\right) k \cdot \exp \left(n_{1} \Psi\right)
\end{aligned}
$$

which applies to the following theoretical reaction:

$$
n_{2} O x_{1}+n_{1} \operatorname{Red}_{2} \rightarrow n_{2} \operatorname{Red} d_{1}+n_{1} O x_{2}
$$

In this reaction, the subscripts 1 and 2 refer to the half-reactions of the tirant (vanadiun) and the sibstance titrated (uranius), respectIvely; Ox is the oxldized form and Red the reduced form of the species in the reaction. Thus $n_{2}=2$ and $n_{1}>1$.

The otier symbols in Eq. (4) have the following meantings and values:

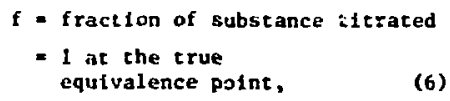

$k=\exp \left[-\frac{n_{1} n_{2}}{n_{1} \div n_{2}} \cdot \frac{F}{R T} \Delta E^{\circ} \cdot\right]$

$\frac{F}{R T}$ (frop Nernst Eq.) = 38.923 at $25^{\circ} \mathrm{C}$,

$$
\begin{aligned}
& \Delta E^{\circ}=E_{1}^{0+}-E_{2}^{0}-+0.98-(+0.52) \\
& =+0.46 \vee \text { vS SHE, } \\
& \Psi=\frac{F}{R T}\left(E-E^{*}\right),
\end{aligned}
$$

E = solucion redox potential,

$$
\begin{aligned}
E^{*} & =-\frac{n_{1} E_{1}^{01}+n_{2} E_{2}^{\prime \prime}}{n_{1}+n_{2}} \\
& =\frac{1(+0.98)+2(0.52)}{1+2} \\
& =+0.67 \mathrm{~V} \text { vs SHE } \\
& =\begin{array}{l}
\text { value of } \bar{E} \text { at the } \\
\text { equivalence point, }
\end{array}
\end{aligned}
$$




$$
\begin{aligned}
& \alpha_{\mathrm{R}}^{\circ}=\frac{\mathrm{C}_{\mathrm{Red}}^{\circ}}{\mathrm{C}_{2}^{\circ}} \text {, } \\
& \begin{aligned}
\mathrm{C}_{\mathrm{Red}}^{\circ}= & \begin{array}{l}
\text { initial concentration } \\
\text { of reduced form of } \\
\text { t1trant (vo } 2+)
\end{array}
\end{aligned} \\
& =4 \mathrm{mg} / 235 \mathrm{~cm}^{3} \text {, } \\
& C_{2}^{0}=\text { Inftial concentration } \\
& \text { (uo }{ }^{2+} \text { ) } \\
& =0.05-1.0 \mathrm{mM} / 235 \mathrm{~cm}^{3} \\
& \text { (10-200 mg } v \text { per sample). }
\end{aligned}
$$

The above equations are not exact for the vanadium/urantum reaction because, as shown in Eq. (3), hydrogen Ions partfcipate in the reaction. Some indication of the effect of $\mathrm{H}^{+}$can be obtalned by calculating $E^{*}$ for the complete reaction. The formula $1 s^{18}$

$$
\begin{aligned}
E^{*}= & \frac{n_{1} E_{1}^{0 *}+n_{2} E_{2}^{0+}}{n_{1}+n_{2}} \\
& +\frac{x}{n_{1}+n_{2}} \cdot \frac{R T}{F} \log \left[H^{+}\right],
\end{aligned}
$$

where $x$ is the number of hydrogen ions in the written reaction and $\left[\mathrm{H}^{+}\right]$is the concentration or activity of $\mathrm{H}^{+}$. In the ticration solution, the total concentratiou of $\mathrm{H}^{+}$is $48 \mathrm{M}$. Substituting this into Eq. (16) yields

$$
E^{*}=+0.67+0.03=0.70 \mathrm{~V} \text { vs SHE. }
$$

Thus, we see that the concentration of $\mathrm{H}^{+}$has a relatively small effect on the theoretical value of the potential at the equivalence point. This value can be compared with those obtained experfmentally:

This work ${ }^{7}:+0.78 \pm 0.01 \mathrm{~V}$ vs SHE Goldbeck and Lerner ${ }^{1}$ : $+0.81 \mathrm{~V}$ Itedrick ${ }^{19}$ (volumetric titration): to.83v

Even for a reaction that conforms strictly to Eq. 14) and does not involve $\mathrm{H}^{+}$ions, the potential (E*) calculated from $\mathrm{Eq}$. (12) does not coinclde exactly with the true equivalence point. This is pointed out by Goldman ${ }^{17}$ and is due to the distortion of the curve caused by the presence of, in this case, the precursor vanadiun(IV). The effect is small, however. Goldman's equarion

$$
f(\text { at } \Psi=0)=1+\alpha_{R}^{\circ}\left(n_{1} / n_{2}\right) k \text {, }
$$

for the worst case (smallest amount of urantum, $\left(10 \mathrm{mg}\right.$ ) shows that $E=E^{*}$ at $f=1.00026$, or $s 1$ ghtly beyond the equivalence point. Another possible perturbation on the above equations (volume changes during titration) is not of concern because of the stolchionetry ${ }^{17}$ and because this is a coulometric titration without volume changes.

To determine the location of the inflection point of the titracton 
curve with respect to the equivalence point in the titration, a program was written for a PDP-8/e minicomputer in double-precision FOcAL to evaluate Eq. (4). For a given set of parameters, we incremented $E$ in 1-mV steps and calculated for each $E$ value through the range of interest. We also calculated the numerical first derivative $(\Delta E / \Delta f$, using the $E$ vs $f$ values) to find the inflection point of the $E$ vs $f$ curve. Table 3 summarizes the results of these calculations. Figure 1 shows a plot of a theoretical $E$ vs $f$ curve.

The data show clearly that, even at the smallest quantity of uranium titrated, the error incurred in assuming the inflection point to be the equivalence point was less than 0.0001 or $0.01 \%$. We also observed experimentally a trend in $E$ at the inflection point (note that

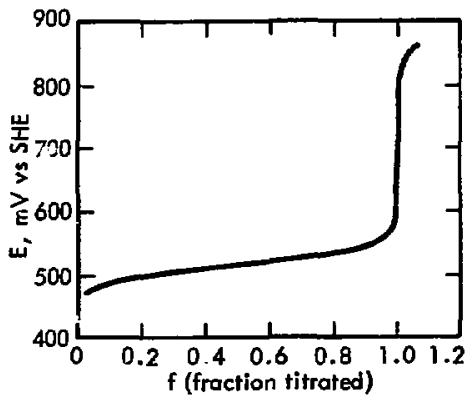

F1g. 1. Theoretical curve for titration of $100 \mathrm{mg}$ uranium(IV) with electrogenerated vanadium(v) at $25^{\circ} \mathrm{C}$. $\alpha_{\mathrm{R}}=8, \mathrm{~F} / \mathrm{RT}=1 / 0.025692$.

$E^{*}=670 \mathrm{mV}$ ) toward moze positive values as the sample size increased. However, here again the effect was not very significant. If, with a constant-potential end-pointdetection technique, one used an end-point value of $673 \mathrm{mV}$ (suitable for $200 \mathrm{mg}$ uranium) in the titration

Table 3. Fraction of uranium(IV) titrated and solution-redox potential at inflection point of $E$ vs $f$ titration curve. $U$ titrated
(mg)
Inflection point (max $\Delta E / \Delta F$ )

f

(mV Vे SHE)

$\begin{array}{rll}200 & 1.000017 & 673 \\ 100 & 1.000024 & 669 \\ 10 & 1.000099 & 651\end{array}$


of $10 \mathrm{mg}$ uranium, the error would be only $+0.02 \%$.

Figures 2 and 3 show two experimental curves obtained for the titration of 124 and $12.4 \mathrm{mg}$ of uranium. We obtained these curves with an incremental plotter interfaced to the system computer.

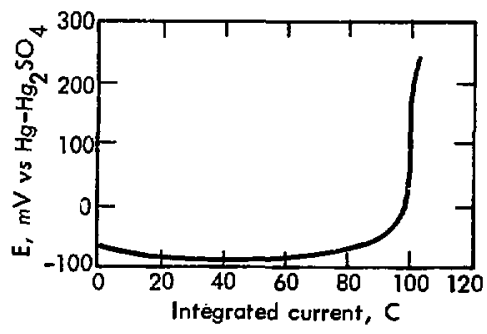

Fig. 2. Experimencal curve for titration of $124 \mathrm{mg}$ uraniun (IV). Titration currents: 300 and $30 \mathrm{~mA}$.

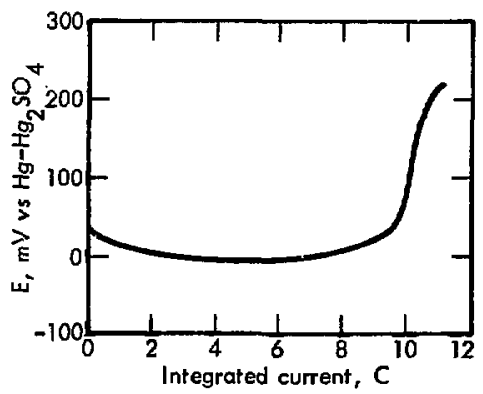

$\mathrm{F}$ Ig. 3. Experimental curve for titration of $12.4 \mathrm{mg}$ uranium(IV). Titration currents: 100 and $10 \mathrm{~mA}$.
The major difference between these experimental curves and the theoretical surve of Fig. 1 is that, in these and all actual titrations at all levels of uranium, there is a gradual change of potentlal toward more negativ: values throughout the first half of the titration. The cause of this is not known; however, wo believe it is due to a slow equilibration of the indicator electrode with the new solution, after exposure to the more oxidizing potential at the end of the previous titration. After the gold or platinum Indicator electrode has soaked in aerated water, the first run of the day also exhibits this behavior.

The nontheoretical shape of the titration curve prior to the endpoint region is a primary reason why we did not investigate the Gran-plot technique $^{20}$ for end-polnt location. Also, the Gran-plot technique is inherently somewhat arbitrary ${ }^{21}$ in how one excrapolates the linear, antilog segments to find the end point. Once a procedure Is adopted, standardlzed chemlcally, then used with unknown samples, the Gran-plot method Is precise and accurate. However, we destred to place the determination on an absolute basis, subject to as few arbitrary parameters as possible, then ascertain 
whether or not there is an inherent bias or error in the determination. So, our approach for end-point detection was to process $E$ vs coulombs data with an algorithm that ylelded the inflection point of the curve, then use that to calculate the quantfty of uranium in the sample.

\section{Study No. 4: Current-Potential Characteristics of Generator Electrode; Titration/Current Efficiency}

Perhaps the most important fartor influencing the accuracy of the determination is the "titration efficlency," which measures how closely the quantity of electricity consumed in e]ectrolysis agrees vith the quantity of uranium titrated. 8 Titration efficiency is thus really a measure, on an absolute basis, of titration accuracy. It depends in part on the "current efficiency" of electrolysis, which in the present work is the agreement between the quantity of electricity consumed and the quantity oi vanadium(V) generated. Goldbeck and Lerner ${ }^{1}$ measured the current efficiency for the electrogeneration of vanadium and found it to be $99.97 \pm 0.05 \%$. To investigate the characteristics of this electrolysis further, we obtained curves of the generator electrode potential as a function of current level, both in the presence and absence of uranlum(IV). Figure 4 shows the results. The solution was that resulting from the additton of the pretitration reagents in the usual manner. The instrumentation stepped the electrolysis current in 2-mA increments from zero at a rate of 2 steps per second and measured and plotted generator-electrode potent:-al after each increment. Because the potential required to sustain a given current level is lower in the presence of uranium, espectally at levels $<100 \mathrm{~mA}$, the data clearly show that uranium, as well as vanadium, was oxidized directly at the electrode. Thus the current efficlency for vanadium(V) generation

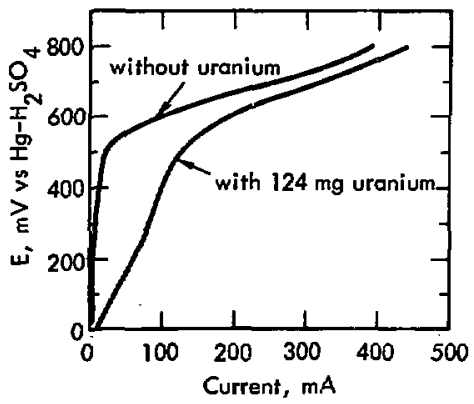

F1g. 4. Electrogeneration of vanadium(V) from varadium (IV) In presence and absence of uranium(IV). 
is considerably lower than $100 \%$ in the presence of urantum, while the titration efficiency is close to $100 \%$.

The direct oxidation of uraniun(IV) beneficla1ly keeps the generator-electrode potential lower -and away from the higher anodic background-current region. However, uranium(IV) contributes less and less to the current as the titration consumes it. Thus, at constant current (e.g., $100 \mathrm{~mA}$ ), the generatorelectrode potential slowly becomes more positive as ticration proceeds. (As discussed below, some of this increase is due to the accumulation of an electrolyce Impurity on the electrode.).

An Indirect, approximate measure of both current efficiency and titration efficiency is the level of background current at the generator electrode in the potential region where it operates during titration. To the extent that the currents of the primary reactions [uranium(IV) or vanadium(IV) oxidations] and the background current are addicive, the latter indicates lowered titration efficiency and a positive error in the determination. Thus, we made measurements of this current under controlled-potential conditions. Table 4 gives these results.

We obtained the Table 4 measurements by connecting controlledpotential coulometric inotrumentation 22 to the reference, counter, and generator (acting here as the working) electrodes of the titration cell. We set the control potential to the values shown, then carried out

Table 4. Background current and accumulated charge measured under controlledpotential electrolysis conditions.

\begin{tabular}{|c|c|c|c|c|c|c|c|c|c|c|c|}
\hline \multirow{2}{*}{$(\mathrm{V} v$} & \multirow{2}{*}{$\begin{array}{l}\text { Potential } \\
\left.\text { vs } \mathrm{Hg}_{3}-\mathrm{Hg}_{2} \mathrm{SO}_{4}\right)\end{array}$} & \multicolumn{5}{|c|}{$\begin{array}{c}\text { Current } \\
(u: \Lambda)\end{array}$} & \multicolumn{5}{|c|}{$\begin{array}{c}\text { Charge } \\
\text { (mg uranlum equivalent) }\end{array}$} \\
\hline & & I min & $2 \min$ & $4 m f n$ & $6 \mathrm{~min}$ & $8 \min$ & $I$ min & 2 min & $4 \mathrm{~min}$ & $6 \mathrm{~min}$ & $8 \mathrm{~min}$ \\
\hline & +0.20 & 0 & & & & & & & & & \\
\hline & +0.30 & 10 & & & & & & & & & \\
\hline & +0.40 & 25 & & & & & & & & & \\
\hline & +0.50 & 70 & 45 & 32 & 25 & 20 & 0.018 & 0.023 & 0.028 & 0.032 & 0.036 \\
\hline & +0.60 & 120 & 110 & 75 & 65 & 55 & 0.028 & 0.036 & 0.050 & 0.061 & 0.069 \\
\hline & +0.70 & 450 & 400 & 275 & 220 & 200 & 0.075 & 0.11 & 0.16 & 0.20 & 0.23 \\
\hline & +0.80 & 1800 & 1500 & 1200 & 1000 & 850 & $0.2 ?$ & 0.33 & 0.54 & 0.69 & 0.83 \\
\hline
\end{tabular}


electrolysis on the solution resultIng from the pretitration reagent addition (except that water was substituted for the diluent). Thus, neither vanadium nor urantum was present. The resulting current vas due to electrode surface reactions; impurities in Reagents 1, 2, and 3; and witer oxidation. We measured both the electrolysis-current level and accumulated charge (in units of $\mathrm{mg}$ of uranium) at the time Intervals indicaced in Table 4.

The following exemplifies the use of such data. The titration, as normally initiated at $300 \mathrm{~mA}$, requires a generacor electrode potential between
+0.65 and +0.75 v vs $\mathrm{Hg}_{-}-\mathrm{Hg}_{2} \mathrm{SO}_{4}$. As discussed in the next section, this potential does not remain constant throughout the titration, rising some 50 to $100 \mathrm{mV}$ as titration proceeds. However, if the potential were to remain constant at, say, $+0.70 \mathrm{v}$, it can be seen from Table 2 that a 6-min electrolysis would entall the accumulation of $0.20 \mathrm{mg}-\mathrm{u}$-equivalent of background charge. These data thus provide some indirect evidence that, even if all other sources of error are eliminated, we can $s t \pm 11$ expect a positive error in titration because of the inherent background current in electrolysis.

\section{Study No. 5: Effect of Phosphoric Acid Impurities on Operating Potential of Generator Electrode}

The considerable experience of NBL with the volumetric and coulometric titrations has revealed that reagent-grade $\mathrm{H}_{3} \mathrm{PO}_{4}$ frequent 1 y contains oxidizable impurities. Thus, it is now routine to add $\mathrm{K}_{2} \mathrm{Cr}_{2} \mathrm{O}_{7}$ to $\mathrm{H}_{3} \mathrm{PO}_{4}$ as a pretreacment procedure before mixing the $\mathrm{H}_{3} \mathrm{PO}_{4}$ with Iton(II) solution. The iron(II) then reduces excess chromium(VI) so the mixture presumably contains no further oxidizable impurtcies.

This procedure 1s satisfactory for the volumetric $\left(\mathrm{K}_{2} \mathrm{Cr}_{2} \mathrm{O}_{7}\right)$ citration, but our present experiments reveal that $\mathrm{K}_{2} \mathrm{Cr}_{2} \mathrm{O}_{7}$ pretreatment lessens, but does uot completely eliminate, an interference in the coulometric titration by a constituent of $\mathrm{H}_{3} \mathrm{PO}_{4}$. The interfering substance may or may not be electrooxidized at the generator electrode; ft may be merely adsorbed on the electrode. Its presence causes the potential of the generator electrode fvs that of the reference electrode, as normally measured in the titration ystem) to be more positive than in its absence or in lower concencracion. Alchough direct oxidation of 
the Impurity is too small to detect, It Indirectly can contribute to a positive error in the titration because the more positive generatorelectrode putential means a higher background current íl electrolysis (see preceding section).

In addition, this interference has a cumulative or "memory effect." The potential that the generator electrode reaches in a series of equal-quantity titrations increases with each successive titration, suggesting that elther the primary contaninant or 1 ts reaction product is adsorbed. Soaking of the electrode overnight in water partially, but does not completely, restore the "Initlal" state* of the electrode. The treatment with HCl, adopted as a standard for the titration system, lowers the generator-electrode potential to a baseline value for the first titration.

Table 5 summarizes the results of a serfes of experfments to test various samples of $\mathrm{H}_{3} \mathrm{PO}_{4}$ for thelr effects on the generator-electrode potential. Before each sample of $\mathrm{H}_{3} \mathrm{PO}_{4}$ was tested, we cleaned the electrode by tolling it in concentrated HCl. The results show considerable differences among

*The state obtai. co upon bolling the electrode in corcent/ated hydrochlor Ic acld ( $\mathrm{HCl}$ ). sources and amoug different lots of the sane manufacturer. Although the Apache Chemical material is reported to be reagent-grade and distilled from Vycor, it did not appear to be of any higher purity than ordinary material. The 3. T. Baker sample caused the generator-electrode potential to exceed $800 \mathrm{mV}$. This produced a black deposit on the electrode, remintscent of the one observed by Goldbeck and Lerner. ${ }^{1}$ This depostt, also visible on some of the cell components, was removable by means of hot, concentrated HC1. Because we found it to be finely divided gold, it appears that the very-posttive-potential polarization caused by the impurity causes the generator electrode to undergo a process analogous to platinization of a platioum electrode. This treatment should be avolded at all costs. If an $\mathrm{H}_{3} \mathrm{PO}_{4}$ sample causes the potential to be too high, it should be discarded immediately.

Electrode poisoning effects of the type found here have also been observed in fuel-cell work involving strong $\mathrm{H}_{3} \mathrm{PO}_{4} \cdot{ }^{23-25}$ Oxidizable impurities have been found that inhibit H-atom deposition ${ }^{23}$ and the oxidation of hydrocarbons. 24 Refluxing of the $\mathrm{H}_{3} \mathrm{PO}_{4}$ with hydrogen peroxide $\left(\mathrm{H}_{2} \mathrm{O}_{2}\right)$ was used in one instance to remove the interference. 23 
Table 5. Maximum generator electrode potential during titrations of $2100 \mathrm{mg}$ quantities of uranium, ising different sources of $\mathrm{H}_{3} \mathrm{PO}_{4}$.

Source

Potentials, in consecutive runs

(mV vs $\mathrm{Hg}-\mathrm{Hg}_{2} \mathrm{SO}_{4}$ )

Mallinkrodt

1ot ARI

$669,690,694$

Malinkrodt

lot VMX

$751,799,815$

Mallınkrodt

lot AGK

(frog NBL)

$612,633,650$

Mallinkrodt

lot AGK

w/o $\mathrm{K}_{2} \mathrm{Cr}_{2} \mathrm{O}$,

$677,688,692,694$

Apache Chemical

679,694 (1st serles)

"High Purity"

693, 701 (2nd series)

Fisher

lot 755162

657,680

J. T. Baker

$>800$ (Black deposit forned on electrode; after 212 runs

lot 519873

stripped whot $\mathrm{HCl}$; found $300 \mu \mathrm{g}$ Au in soln by atomic

absorption spectrophotometry)

Brititin Drug House

692, 749 (Material more viscous than L.S. $\mathrm{H}_{3} \mathrm{PC}_{4}$; only

Analar lot 2063690 $28 \mathrm{ml}$ ys $45 \mathrm{ml}$ dellvered in usual time.) 
Bravacos et al. ${ }^{24}$ by means of standard addition experiments, concluded that the constituents polsoning their electrodes were phosphorous acld $\left(\mathrm{H}_{3} \mathrm{PO}_{3}\right)$ and hypophosphorous acid $\left(\mathrm{H}_{3} \mathrm{PG}_{2}\right)$, both of which apparently adsurbed on the elec crode and were oxidized in the potfntial region of the experiments.

We plan to examine samples of the $\mathrm{H}_{3} \mathrm{PO}_{4}$ descrtbed in Table 5 to try to Identify the constituent causing the detrimental behavior.

\section{Study No. 6: Reproducibility of Reagent Solution Delivery}

No studies have been carried out to determine the allowable variation in volumes of the four pretitration reagents for the exact conditions of tnis automated titration. however, previous worti on the manual method 6,26 and recent experience Indicate that, at least for chemical reasons, close control is not required.

The sulfimic acid solution volume probably can be $5 \pm 1 \mathrm{~cm}^{3}$, wth an excess probably more colerable than a deficiency. The same is true of the $\mathrm{HNO}_{3}$-molybdenum(VI) reagent, where there must be sufficient solution to destroy the excess Iron(II) from the preceding reagent. Here, a volume of $10 \pm 2 \mathrm{~cm}^{3}$ probably is reasonable. In the case of the 1 ron (II) $-\mathrm{H}_{3} \mathrm{PO}_{4}$ reagent, there must be suffictent fron(II) to effect rapid reduction of the largest possible quantity of urantum, but not so much that a great extess is present. Also, the volume of solution should not vary so much that it will affect the mixing characteristics of the solution during the reduction step and/or markedly change the total volume of the final titration mixture. This 13 also true of the vanadium(IV)$\mathrm{H}_{2} \mathrm{SO}_{4}$ diluent, where a relatively small percentage change in volume delivered results in a significant variation in $\mathrm{cm}^{3}$ of volume. In consideration of this effect, the nominal volumes of the iron(II) $-\mathrm{H}_{3} \mathrm{PO}_{4}$ and the diluent should be, respectively, 45 $\pm 3 \mathrm{~cm}^{3}$ and $160 \pm 5 \mathrm{~cm}^{3}$.

\section{Factors that influence the} volumes of reagent solutions delivered includa driving pressure, vartation in the level -- or head -- of solution in the reagent containers, temperarure, and changes in flow passages due to accumulation of solid material. Valve wear should not be a factor in affecting solution flow rates. When checking flow rates of reagent solutlons, we decermined the quantictes delivered by weighing the solutions. 
The data In Table 6 show that the short-term reproducitility of solution delivery at constant pressure* is we11 within tolerances. The only variation ncted here, occasionally, is a hysteresis in the driving-pressure regulator. This causes the volume delivered to drop slightly on successive deliveries, until the regulator finally responds and bleeds in more gas to restore the driving pressure.

*Effective pressure equals driving pressure minus solution level.
Table 7 shows the effects of a variation in both driving pressure and level of solutions in the containers on the volumes of reagents delivered. The driving pressure is typically held with $\pm \mathrm{n} \pm 2 \mathrm{kPa} \quad( \pm 0.3$ psi). Thus, this is a minor factor in operating system variation. The solution level, on the other hand, is the most significant variable of all in determining volumes of solutions delivered. The 56-cm change in level for these measuremencs is equiva'ent to a pressure change of $5.5 \mathrm{kPa}$ (0.8 psi) for pure water. The effect Is within tolerance for all reagents

Table 6. Short-term reproducibilfty of delivery of reagents $\$ 82.8 \mathrm{kPa}(12.0$ psi) driving pressurel.

Weights of solution

(g)

\begin{tabular}{cccc}
\hline Sulfamic actd & $\mathrm{Fe}(\mathrm{II})-\mathrm{H}_{3} \mathrm{PO}_{4}$ & $\mathrm{WNO}_{3}-\mathrm{Mo}(\mathrm{VI})$ & Diluent \\
\hline 6.048 & 78.4 & 12.07 & 161.3 \\
6.068 & 79.1 & 12.10 & 161.1 \\
6.065 & 79.3 & 12.12 & 160.7 \\
6.058 & 79.5 & 12.09 & \\
6.058 & 79.6 & & \\
6.050 & 79.4 & & \\
& 77.8 & & \\
& 77.3 & & \\
& 77.8 & & \\
& 78.1 & & \\
& 78.5 & &
\end{tabular}


Table 7. Effects of driving pressure and solution level on volumes of reagel. delivered during automatic titration.

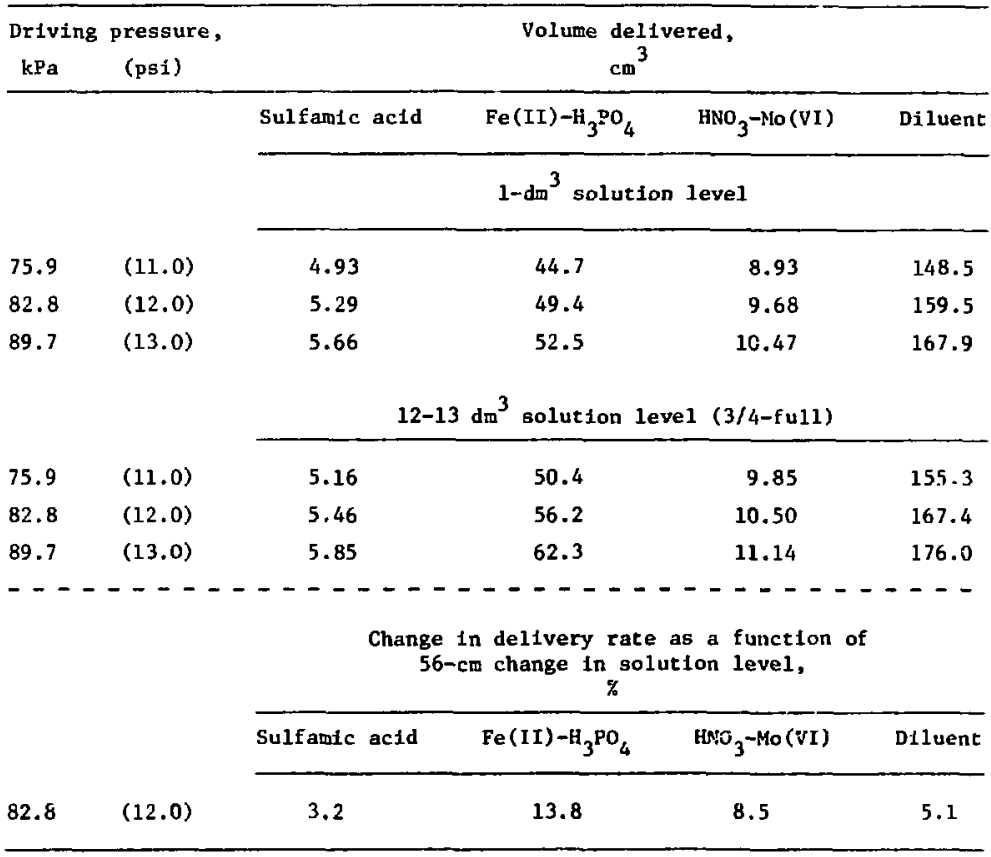

except the very dense $\operatorname{Iron}(\mathrm{II})-\mathrm{H}_{3} \mathrm{PO}_{4}$ solution. As a result of these measurements, we reduced the contalner size for this reagent so the actual level change experienced in the prototype system will be one-half that shown in Table 7 .

Table 8 11sts some data that Hllugtrate the lons-term reproduci- bility of reagent delivery. We made these measurements without readjustment of the pressure regulator or mirrometer valves, the systes was in continual use, and the solution levels were at varlous helghts. It appears that, with all the factors involved, we achievea adequate reproductbility in the solution delivery. 
Table 8. Long-term reproductbility of reagent delivery. [Pressure: 83.5-81.4 $\mathrm{kPa}(12.1-11.8 \mathrm{ps})$, temperature: $22-25^{\circ} \mathrm{C}$, head variation: $\left.230 \mathrm{~cm}\right]$

\begin{tabular}{|c|c|c|c|c|}
\hline \multirow[b]{2}{*}{ Date } & \multicolumn{4}{|c|}{$\begin{array}{c}\text { Flow rate } \\
\text { (g/sec) }\end{array}$} \\
\hline & Sulfamic acid & $\mathrm{Fe}(\mathrm{II})-\mathrm{H}_{3} \mathrm{PO}_{4}$ & $\mathrm{HNO}_{3}-\mathrm{Mo}(\mathrm{VI})$ & Diluent \\
\hline Oct. 14,1974 & 1.375 & 0.583 & 0.771 & 3.75 \\
\hline Oct. 25 & 1.367 & 0.598 & 0.777 & 3.70 \\
\hline Nov. 1 & 1.353 & 0.580 & 0.761 & 3.66 \\
\hline Nov. 20 & 1.405 & 0.611 & 0.755 & 3.64 \\
\hline Dec. 17 & 1.385 & 0.600 & 0.745 & 3.60 \\
\hline Apr. 29, 1975 & 1.363 & 0.546 & 0.726 & 3.55 \\
\hline Oct. 13 & 1.389 & 0.618 & 0.749 & 3.73 \\
\hline Feb. 28,1976 & 1.426 & 0.605 & 0.733 & 3.80 \\
\hline
\end{tabular}




\section{References}

1. C. G. Goldbeck and M. W. Lerner, Anal. Chem. 44,594 (1972).

2. C. G. Goldbeck and M. W. Lerner, In Annual Progress Report for the Period July 1971. to June 1972, U.S. Atomic Energy Comission, New Brunswick Laboratory, N.J., Rept. NBL-265 (1972), pp. 5-20

3. C. G. Goldbeck, M. W. Lerner, and G. E. Peoples, in Annual Progress Report for the Perlod July 1972 to June 1973, U.S. Atomic Energy Commiss Lor, New Brunswick Laboratory, N.J,, Rept. NBL-267 (1973), Pp. 29-31.

4. C. G. Goldbeck, In Annual Progress Report for the Perlod July 1973 to June 1974, U. ". Atomic Energy Commission, New Brunswick Laboratory, N.J., Rept. NBL-272 (1974), PP. 36-37.

5. W. Davies and W. Gray, Talanta 11, 1203 (1964).

6. A. R. Eberle, M. W. Lerner, C. G. Goldbeck, and C. J. Rodden, Titrimetric Deterwination of Uranium in Product, Fuel, anc Scrap Materials after Ferrous Ion Reduction In Phosphorlc Acld, U.S. Atomic Eaergy Commission, New Brunswlck, N.J., Ket $:$. NBL-252 (1970).

7. J. E. Harrar, W. G. Boyle, J. D. Breshears, C. L. Pomecnack1, H. R. Brand, A. M. Kray, R. J. Sherry, and J. A. Pastrone, "An Aut Jmated Sample Processing anr. Titration System for the Determinatioil of Uranium in Nuclear Materials," In Proc. Inst. of Nuclear Mater lals Management Mtg., Seattle, 1976 (Inst. of Nuclear Materials Managewrint, Manhattan, Kansas, 1976).

8. J. J. Lingane, Electroanalytical Chemistry (Interscience, New York, 1958), 2nd Ed., pp. 488-490.

9. A. R. Eberle and M. W. Lerner, in Annual Progress Report for the Perlod July 1970 to June 1971, U.S. Atomic Energy Comissiou, New Brunswick Laboratory, N.J., Rept. NBL-262 (1971), Pp. 5-16.

10. A. 2. Eberle and M. W. Lerner, In Annual Progress Report for the Period July 1969 to June 1970, U.S. Atomic Energy Commisston, New Brunswick Laboratory, N.J., Rept. NBL-258 (1970), PP. 22-25.

11. L. P. Rigdon a.1d J. E. Harrar, Anal. Chem. 41, 1673 (1969).

12. J. E. Harrar and R. J. Sherry, Anal. Chem. 47, 60i (197j).

13. J. A. Goldman, J. Electroanal. Chem. 14, 373 (1967); 1841 (1968).

14. J. A. Goldiaan, J. Electroanal. Chem. :-8, 41 (1968).

15. N. S. Ast:akh1na and V. G. Gurev1ch, Ukrr. J. Chem. 36, 886 (1970).

16. Y. Harcus, J. Phys, Chem. 62, 1314 (1958). 
17. J. A. Goldman, J. Electroanal. Chem. 16, 47 (1968).

18. J. J. Lingane, Electroanalytical Chemistry (Interscience, New York, 1958), 2nd Ed., Pp. 139-141.

19. C. E. Hedrick, in Annual Progress Report for tine Pericd July 1S d to June 1969, U.S. Atomic Energy Commission, New Brunswick Laboratory, N.J., Rept. NBl-250, pp. 16-19.

20. T. Anfält and D. Jagner, Anal. Chim. Acta 57, 165 (1971).

21. J. W. Frazer, A. M. Kray, W. Se11g, and R. Lim, Anal. Chem. 47, 869 $(1975)$.

22. J. E. Harrar and E. Behrin, Anal. Chen. 39, 1230 (1967).

23. S. B. Brummer, J. I. Ford, and M. J. Turner, J. Phys. Chem. 69, 3424 (1965).

24. J. Bravacos, M. Bonnemay, E. Levart, A. Pilla, C. R. Acad. Sci. Paris c265, 337 (1967).

25. K. Klinedinst, J. A. S. Bett, J. MacDonald, and P. Stonehart, J. Electroana1. Chem. 51, 281 (1974).

26. L. Z. Bodnar and M. W. Lerner, in Annual Progress Report for the Perfod July 1973 through June 1974, U.S. Atomic Energy Comission, New Brunswick Laboratory, N.J., Rept. NBL-272 (1974), jp. 13-25. 


\section{Appendix: Procedure for Testing VOSO ${ }_{4}$ Solution for Vanadium(V) by Controlled-Potential Coulometry}

Equipment: 1. Controlled-potential coulometry system

2. Electrolysis cell with platinum-gauze working electrode

Reagents: $\quad 1.5 \mathrm{M} \mathrm{H}_{3} \mathrm{PO}_{4}$

$0.1 \mathrm{M} \mathrm{H}_{2} \mathrm{SO}_{4}$

Standard vanadium(V) solution; $1 \mathrm{mg}$ vanadium/ $\mathrm{cm}^{3}$ (optional)

Procedure: A. Preparation of VoSO $_{4}$ Solution

1. Weigh out and place in a $100 \mathrm{~cm}^{3}$ beaker $7.5 \mathrm{~g}$ of $\mathrm{vosO}_{4} \cdot 2 \mathrm{H}_{2} \mathrm{O}$ salt.

2. Place a magnetic stirring bar in the beaker, then add from a graduated cylinder $50 \mathrm{~cm}^{3}$ of $0.1 \mathrm{M} \mathrm{H}_{2} \mathrm{SO}_{4}$.

3. Stir the solution 5 to 10 minutes until the salt has dissolved.

B. Pretreatment of Platinum Electrode

1. Soak the electrode for $1 \mathrm{~h}$ in $50 \% \mathrm{HNO}_{3}$, prepared fresh so It is warm at the start of pretreatment. Rinse with water. Immerse the electrode in hot, concentrated HCl, then allow to soak in the cooling acid for $1 \mathrm{~h}$. Rinse with water.

2. Allow the electrode to soak in water overnight before using.

C. Coulometric Analysis Procedure

I. FII1 both reference and counter-electrode compartments of the cell with $1.5 \mathrm{M} \mathrm{H}_{3} \mathrm{PO}_{4}$.

2. Before coulometric measurement, deoxygenate solutions with inert gas for seven minutes. 
3. Carry out several blank dereminations with cell solution consisting of $10 \mathrm{~cm}^{3}$ of $\mathrm{H}_{2} \mathrm{O}$ and $15 \mathrm{~cm}^{3}$ of $1.5 \mathrm{MH}_{3} \mathrm{PO}_{4}$. Deoxygenate the solution thoroughly, and electrolyze the solution for 10 minutes at t0.40 v vs SCE. Repeat blank runs until the background current: is below $25 \mathrm{HA}$ and the blank is less than $0.015 \mathrm{mg}$ of vanadium.

4. Determine the quantity of vanadium(V) In $10 \mathrm{~cm}^{3}$ of voso, solution prepared as described above, by addition of voso 4 solution to $15 \mathrm{cra}^{3}$ of $1.5 \mathrm{M} \mathrm{H}_{3} \mathrm{PO}_{4}$ in the cell, deoxygenation of the cell solution, and reduction as in Step c3.

5. Correct the measurements of the $\mathrm{VoSO}_{4}$ solution for the blank value determined in Step $c 3$.

6. The net quantity of vanadium(V) found in the coulometric detemination, multiplled by 1.3 , gives the equivalent quantity of urantum that would be oxidized by the vanadium(V) in $160 \mathrm{~cm}^{3}$ of diluent made with this sample of VoSO $_{4} \cdot 2 \mathrm{H}_{2} \mathrm{O}$. This must be less than $0.05 \mathrm{mg}$ uraniur.

D. Standard Addition Determination of Vanadium(V) (Optional)

1. After determination of vanadium(V) in the voso 4 solution in Step C4, switch the potentlostat to standby. Do not rinse out the cell solution.

2. Add to the cell solution $0.1 \mathrm{~cm}^{3}$ of a solution containing $1 \mathrm{mg}$ vanadium(V) prepared as described below.

3. Continue deoxygenating the solution for 3 minutes, then electrolyze the solution at $+0.40 \mathrm{~V}$ for 10 minutes or until the current decreases to $25 \mu \mathrm{A}$. The readout should ind 1 cate $2100 \mathrm{\mu g}$ of vanadium, and 90 to $95 \%$ of the quantity of vanadium(V) added should be recovered.

4. Correct the quantity of vanadium(v) found in the vosO $_{4} \cdot 2 \mathrm{H}_{2} \mathrm{O}$ for the quantity of added standard vanadium(V) found. 
E. Preparation of Standard Vanadium(V) Solution

1. Weigh out and place in a $250 \mathrm{~cm}^{3}$ Erlenmeyer flask $20.1 \mathrm{~g}$ of high-purity vanadium wire.

2. Add to the flask $5 \mathrm{~cm}^{3}$ concentrated $\mathrm{HNO}_{3}$ and $5 \mathrm{~cm}^{3}$ concentrated $\mathrm{H}_{2} \mathrm{SO}_{4}$. Heat on a hot plate until dissolution of the metal is complete. If necessary, add a few $\mathrm{cm}^{3}$ more of concentrated $\mathrm{HNO}_{3}$. Heat strongly for 30 minutes after dissolution is complete.

3. Cool the solution to room temperature, add $10 \mathrm{~cm}^{3} \mathrm{H}_{2} \mathrm{O}$, mix, then add $2 \mathrm{~g}$ ammonium persulfate $\left(\mathrm{NH}_{4}\right)_{2} \mathrm{~S}_{2} \mathrm{O}_{\mathrm{B}}, \mathrm{mlx}$, and heat again on the hot plate.

4. Bring the solution to a gentle boll for at least 15 minutes to ensure that all of the vanadium has been oxidized to vanadium(V) and the excess persulfate has been destroyed.

5. Transfer the solution to a $100 \mathrm{~cm}^{3}$ volumetric flask and dilute to volume with $\mathrm{H}_{2} \mathrm{O}$.

6. Verify the concentration of the vanadium standard solution by soulometric determination as described in $c$, taking $1 \mathrm{~cm}^{3}$ aliquots of the standard solution and electrolyzing at $+0.55 \mathrm{~V}$ vs SCE. 11

Notes: 1 . The use of $\mathrm{H}_{3} \mathrm{PO}_{4}$ supporting electrolyte ensures that moderate amounts of impurity iron(III) w111 not interfere.

2. The large excess of vanadium(IV) compared to the vanadium(V) requires the use of a more negative potential for the VOSO $_{4}$ solution than that recommended in Ref. 11 for relatively pure vanadium(V) solutions. Even so, complete recovery in the standard addition procedure is still not actained. So a correction for this must be applied. 